\title{
Two new species of centipedes, Tygarrup daliensis sp. nov. (Mecistocephalidae) and Australobius cangshanensis sp. nov. (Lithobiidae), from Southwestern China
}

\author{
J.L. CHAO ${ }^{1 *}$, K.S. LEE $^{2}$, Z.Z. YANG ${ }^{3} \&$ H.W. CHANG ${ }^{4}$ \\ ${ }^{1}$ Jui-Lung Chao, Invertebrate Section, Biology Department, National Museum of Natural Science (NMNS), 1 Guancian Road, \\ Taichung 40453, Taiwan, R.O.C., E-mail: chaojuilung@gmail.com, *Corresponding author \\ ${ }^{2}$ Kwen-Shen Lee, Invertebrate Section, Biology Department, National Museum of Natural Science (NMNS), 1 Guancian Road, \\ Taichung 40453, Taiwan, R.O.C. \\ ${ }^{3}$ Zi-Zhong Yang, Institute of Entomoceutics Research, Dali University, Dali, Yunnan, China \\ ${ }^{4}$ Hsueh-Wen Chang, Department of Biological Sciences, National Sun Yat-Sen University, \\ 70 Lien-Hai Road, Kaohsiung 804, Taiwan, R.O.C.
}

\begin{abstract}
Two new species of Chilopoda from Yunnan Province, China, are described as new: Tygarrup daliensis sp. nov. (Geophilomorpha, Mecistocephalidae) and Australobius cangshanensis sp. nov. (Lithobiomorpha, Lithobiidae) Tygarrup daliensis sp. nov. differs from other Tygarrup species by its each side of clypeal plagula with up to 15 setae, arranged in three irregular rows; labral posterior ala rough, with about 10 longitudinal slanting stripes near to mid-piece tooth; mandible with 9 pectinate dentate lamellae, $1^{\text {st }}$ mandibular pectinate lamella bearing 6 teeth; each coxopleuron of last leg-bearing segments with about 50 pores of various size. Australobius cangshanensis sp. nov. is distinguished from congeners by a row of about 60 short setae transversely on each posterior part of $6^{\text {th }}$ and $7^{\text {th }}$ sternites; forcipular coxosternite with 7-10 coxosternal teeth, and porodonts between $5^{\text {th }}$ and $6^{\text {th }}$ or between $4^{\text {th }}$ and $5^{\text {th }}$ innermost teeth.
\end{abstract}

Keywords. Cangshan, Chilopoda, Dali, taxonomy, Yunnan.

\section{INTRODUCTION}

$\mathrm{T}$ he centipedes of Southwest China were rarely investigated. The Institute of Entomoceutics Research, Dali University, collected and deposited many insect, spider and myriapod specimens from the Yunnan region over the last ten years. We studied specimens of centipedes from Dali University and some new material collected by ourselves. Our study recorded six known species of centipedes in the region (Tab. 1): Mecistocephalus rubriceps Wood, 1862, Bothropolys yoshidai Takakuwa, 1939, Cermatobius longicornis (Takakuwa, 1939), Scolopendra dehaani Brandt, 1840, Scolopendra subspinipes mutilans L. Koch, 1878 and Cryptops doriae Pocock, 1891. Moreover, we revealed two new species, Tygarrup daliensis sp. nov. (Geophilomorpha, Mecistocephalidae) and Australobius cangshanensis sp. nov. (Lithobiomorpha, Lithobiidae).

\section{MATERIAL AND METHODS}

The material was studied using stereo-microscope and SEM. Type specimens are preserved in $75 \%$ alcohol and deposited in the department of Biology, National Museum of Natural Science (NMNS), Taichung, Taiwan. Terminology for external anatomy follows Bonato et al. (2010). The following abbreviations are used in the text and tables: a-anterior, $\mathrm{C}$ - coxa, $\mathrm{F}-$ femur, $\mathrm{m}$-median, $\mathrm{p}$ - posterior, $\mathrm{P}$ - prefemur, $\mathrm{t}$ - trochanter, $\mathrm{T} / \mathrm{TT}$ - tergite/tergites, $\mathrm{Ti}$ - tibia. 
Table 1. The records of six species of Chilopoda from the Yunnan Province, China.

\begin{tabular}{|c|c|}
\hline Species & Material examined \\
\hline $\begin{array}{l}\text { Mecistocephalus rubriceps } \\
\quad \text { Wood, } 1862\end{array}$ & 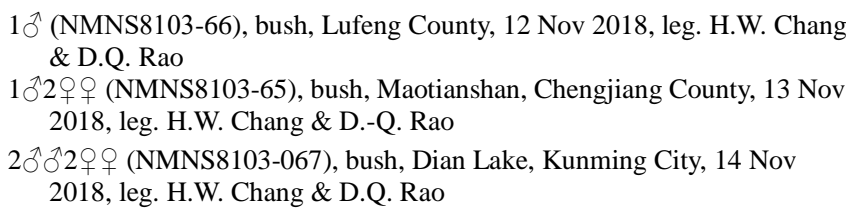 \\
\hline $\begin{array}{l}\text { Bothropolys yoshidai } \\
\text { Takakuwa, } 1939\end{array}$ & $\begin{array}{l}1 \jmath^{\Uparrow} 3 \text { 우 (NMNS8103-063), forest floor, Weibaoshan, Weishan County, } 18 \\
\text { Nov 2018, leg. J.L. Chao }\end{array}$ \\
\hline $\begin{array}{l}\text { Cermatobius longicornis } \\
\quad(\text { Takakuwa, 1939) }\end{array}$ & $\begin{array}{l}1 \text { ㅇ (NMNS8103-064), bush, Maotianshan, Chengjiang County, } 13 \text { Nov } \\
\text { 2018, leg. H.W. Chang \& D.Q. Rao }\end{array}$ \\
\hline Scolopendra dehaani Brandt, 1840 & $\begin{array}{l}\text { Dali University Coll., forest floor, Cangshan, Dali City, } 15 \text { May 2011, leg. } \\
\text { Z. Z. Yang }\end{array}$ \\
\hline $\begin{array}{l}\text { Scolopendra subspinipes mutilans } \\
\quad \text { L. Koch, } 1878\end{array}$ & $\begin{array}{l}\text { Dali University Coll., forest floor, Cangshan, Dali City, } 15 \text { May 2011, leg. } \\
\text { Z. Z. Yang }\end{array}$ \\
\hline Cryptops doriae Pocock, 1891 & $\begin{array}{l}1{ }^{1} 1 \text { ( NMNS8103-68), bark, Cangshan, Dali City, } 29 \text { Oct 2011, leg. L. } \\
\text { Yang } \\
1{ }^{\lambda} \text { (NMNS8103-69), bush, Cangshan, Dali City, } 17 \text { May 2011, leg. H.W. } \\
\text { Chang } \\
1{ }^{\lambda} \text { (NMNS8103-70), bush, Lijiang City, } 08 \text { May 2011, leg. H.W. Chang } \\
1{ }^{1} 1 \text { (NMNS8103-71), forest floor, Weibaoshan, Weishan County, } 18 \\
\text { Nov 2018, leg. J.L. Chao }\end{array}$ \\
\hline
\end{tabular}

TAXONOMY

Order Geophilomorpha Pocock, 1895

Family Mecistocephalidae Bollmann, 1893

Genus Tygarrup Chamberlin, 1914

Tygarrup daliensis Chao, Lee, Yang \& Chang, sp. nov.

(Figures 1-11)

Material examined. Holotype: 우 (NMNS81 03-013), forest floor, Cangshan, Dali City, Yunnan Province, $25^{\circ} 42^{\prime} \mathrm{N}, 100^{\circ} 07^{\prime} \mathrm{E}, 2500 \mathrm{~m}, 08$ May 2011, leg. Yuan He. Paratypes: 3 우 (NMNS8103-014), same data as holotype. Other material: $1 \hat{\jmath}, 1$ 우 (NMNS8103-015), same locality as holotype, 29 Oct 2011, leg. Z.Xu. Bao; 1 으 (NMNS8103-016), same locality as holotype, 14 Jul 2010, leg. R.Y. Nan; 2우 (NMNS8103-017), rotten wood, Weishan
County, Yunnan Province, $25^{\circ} 10^{\prime} \mathrm{N}, 100^{\circ} 21^{\prime} \mathrm{E}$, 2506 m, 16 Nov 2018, leg. Z.-Z. Yang \& J.L. Chao; 1ㅇ (NMNS8103-018), forest floor, Tengchong County, Yunnan Province, $25^{\circ} 01^{\prime} \mathrm{N}$, 98²9'E, 1718 m, 17 Jul 2011, leg. L. Yang.

Etymology. Refers to the type locality.

Diagnosis. A Tygarrup species invariantly with 45 leg-bearing segments. Body length about $40 \mathrm{~mm}$. Head 1.4 times as long as wide. Each clypeal plagula with about 15 setae, arranged in three irregular rows, each seta inside an insula. Ventral surface of labral posterior ala rough, each side with about 10 longitudinal slanting stripes near mid-piece tooth; posterior margin of labral ala without a fringe. Mandible with 9 pectinate dentate lamellae, $1^{\text {st }}$ lamella bearing 6 teeth, average intermediate lamella bearing ca. 16 teeth. Forcipular articles I with a large denticle, II and III each with a small denticle, tarsungulum with a basal denticle. Sternal 
sulcus apparently not furcated. Each coxopleuron of last leg-bearing segments with about 50 pores of various size, without a macropore distinct from other pores.
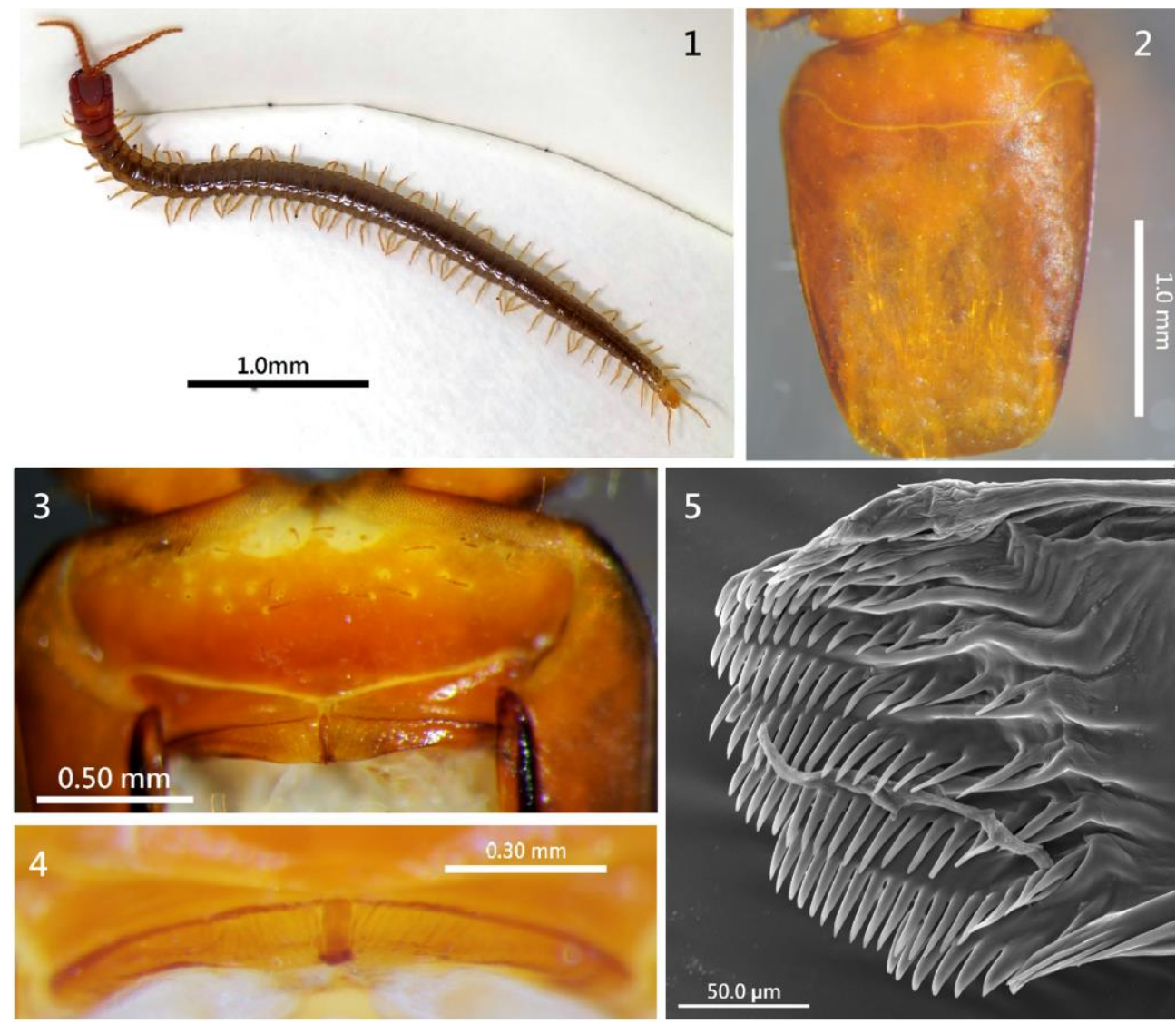

Figures 1-5. Tygarrup daliensis sp. nov. 1 = habitus, dorsal view; 2 = cephalic plate; 3 = clypeus and labrum; 4 = labrum; 5 = mandibular dentate lamellae (1-4: NMNS8103-017; 5: NMNS8103-016).

Description. A total of 45 leg-bearing segments. Body length of adults up to about $40 \mathrm{~mm}$. Body colour: head, forcipular segment and $1^{\text {st }}$ leg-bearing segment dark red, last legbearing segment and legs yellow, other legbearing segments yellow with dark patches (Fig. 1). Antennae: with 14 articles. Cephalic plate: about 1.4-times as long as wide, transverse suture uniformly rounded (Fig. 2). Clypeus: areolate part only present along anterior margin of head, areolate part without smooth insulae, a long seta on each side of the areolate part; an entire plagula covering most of clypeus, without a mid-longitudinal areolate stripe; each clypeal plagula with $11-15$ setae, arranged in three irregular rows as follows: 4-7 setae along each anterior margin of plagula (1-2 intermediate, $3-$ 5 lateral), and 7-8 setae arranged in two irregular rows on each side of the plagula (Fig. 3); each seta inside a smooth insula. Labrum: anterior ala triangular, medial margin reduced to a vertex; posterior margin of each side-piece sinuous; ventral surface of labral posterior ala rough, each side with about 10 longitudinal slanting stripes near mid-piece tooth (Fig. 4); posterior margin of labral ala without a fringe. 
Spiculum absent (Fig. 3). Buccae without setae. Mandible: 9 pectinate dentate lamellae (Fig. 5) with variable teeth (Tab. 2).

Table 2. Number of teeth on every mandibular dentate lamella in Tygarrup daliensis sp. nov.

\begin{tabular}{lllllllllll}
\hline $\begin{array}{l}\text { Pectinate } \\
\text { lamella }\end{array}$ & $\mathbf{1}^{\text {st }}$ & $\mathbf{2}^{\text {nd }}$ & $\mathbf{3}^{\text {rd }}$ & $\mathbf{4}^{\text {th }}$ & $\mathbf{5}^{\text {th }}$ & $\mathbf{6}^{\text {th }}$ & $\mathbf{7}^{\text {th }}$ & $\mathbf{8}^{\text {th }}$ & $\mathbf{9}^{\text {th }}$ \\
\hline $\begin{array}{l}\text { Number } \\
\text { of teeth }\end{array}$ & 6 & 18 & 17 & 16 & 15 & 12 & 10 & 8 & 8 \\
\hline
\end{tabular}

First maxillae: lateral lappet lacking, each coxal projection about 1.4 times as long as wide, internal margin with some setae; each telopodite about 4 times as long as wide, distal articles curved inward (Fig. 6). Second maxillae: article I of telopodite about 4 times as long as wide; article III about 2.4 times as long as wide, densely covered with setae (Fig. 6); apical claw very small (Fig. 7). Forcipules: trochanteroprefemur about 1.3 times as long as wide, with a large distal tooth; both femur and tibia with a small tooth (Fig. 8); tarsungulum with a large basal denticle.
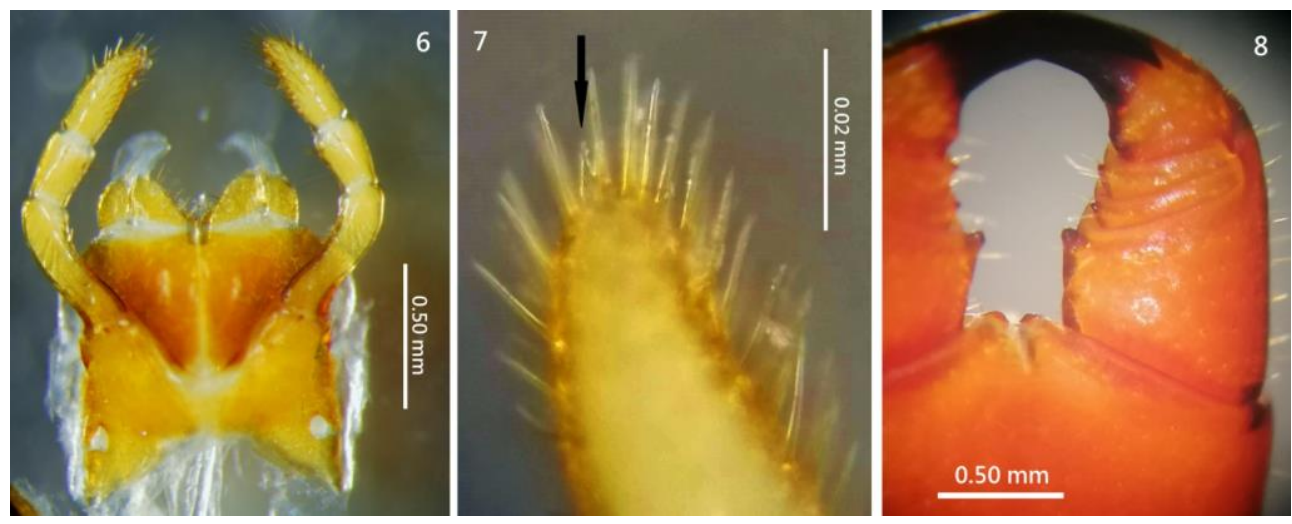

Figures 6-8. Tygarrup daliensis sp. nov. $6=$ first and second maxillae; $7=$ apical claw (arrow) of second maxillae; $8=$ forcipules (6-7: NMNS8103-016; 8: NMNS8103-015).

Sternites: sternal sulcus not furcated, apparently present from $1^{\text {st }}$ to $23^{\text {rd }}$ sternites (Figs. 910); sternal pores lacking in both sexes. Last leg-bearing segment: last sternite about 1.2 times as long as wide; about 50 pores of various sizes on each coxopleuron, without a macropore distinct from other pores (Fig. 11). A large anal pore on each ventro-lateral sides of telson (Fig. 11).

Remark. Fourteen species have hitherto been described within the genus Tygarrup Chamberlin, 1914, with only one species, Tygarrup poriger (Verhoeff, 1942), from Shigatse, China. Verhoeff (1942) originally described a new genus Brahmaputrus and type species B. poriger, with 45 leg-bearing segments; each side of clypeal plagula with 6 setae; mandible with 9 pecti- nate lamellae, $1^{\text {st }}$ lamella with 3 teeth; each coxopleuron of last leg-bearing segments with 2122 pores of various sizes. Crabill (1968) considered the genus Brahmaputrus Verhoeff, 1942, as a synonym of Tygarrup Verhoeff, 1942. Shinohara (1965) described Tygarrup nepalensis from Himalaya, with 45 leg-bearing segments; each side of clypeal plagula with 8 setae; mandible with $8-9$ pectinate lamellae, $1^{\text {st }}$ lamella with 3 teeth; each coxopleuron of the last leg-bearing segment with 20 pores of various sizes. Tygarrup daliensis sp. nov. differs from other Tygarrup species by its clypeal plagula with more setae, arranged in three irregular rows; ventral surface of labral posterior ala rough; mandible with more pectinate dentate lamellae and teeth; each coxopleuron of the last legbearing segment with more pores (Tab. 3). 

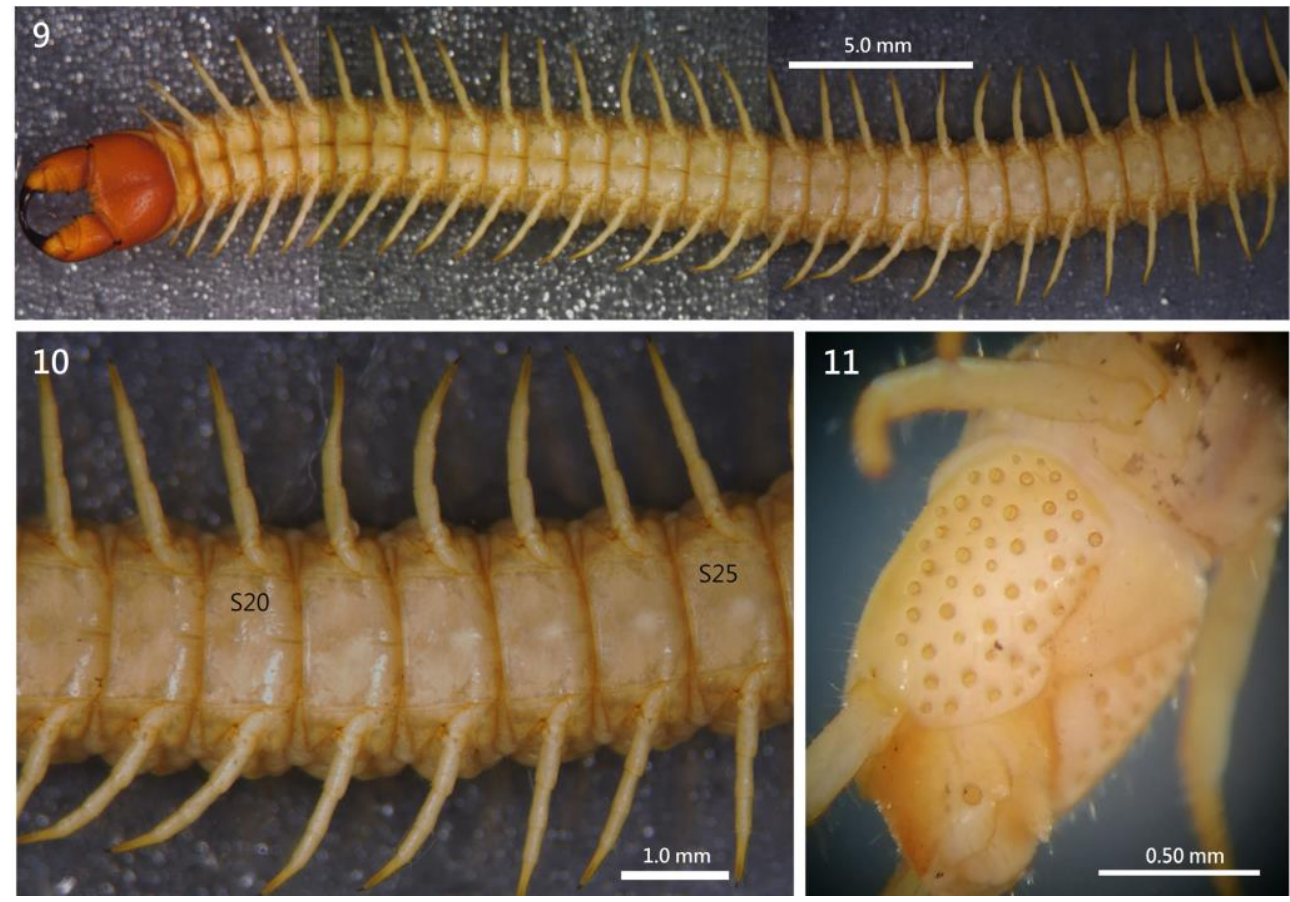

Figures 9-11. Tygarrup daliensis sp. nov. $9=$ anterior leg-bearing segments, ventral view; $10=18^{\text {th }}-25^{\text {th }}$ sternites; 11 = last leg-bearing segment, lateral view (9-11: NMNS8103-015).

Table 3. Main morphological characters of the eight known Asian species of Tygarrup Chamberlin, 1914.

\begin{tabular}{|c|c|c|c|c|c|}
\hline \multicolumn{2}{|c|}{ Tygarrup species } & $\begin{array}{c}\text { T. daliensis } \\
\text { sp. nov. }\end{array}$ & T. poriger & T. nepalensis & T. javanicus \\
\hline \multicolumn{2}{|c|}{ Description from } & This paper & $\begin{array}{c}\text { Verhoeff (1942) } \\
\text { Crabill (1968) }\end{array}$ & Shinohara (1965) & $\begin{array}{c}\text { Verhoeff (1937) } \\
\text { Titova (1983) } \\
\text { Bonato et al. (2004) } \\
\text { Bonato \& Minelli } \\
\text { (2010) }\end{array}$ \\
\hline \multirow{2}{*}{$\begin{array}{l}\text { Clypeal } \\
\text { setae (pair) }\end{array}$} & areolate part & 1 & 0 & 1 & 1 \\
\hline & plagula & $11-15$ & 6 & 8 & $5-7$ \\
\hline \multirow[b]{2}{*}{ Mandible } & lamellae & 9 & 9 & $8-9$ & 6 \\
\hline & $\begin{array}{l}\text { teeth of } 1^{\text {st }} \\
\text { lamella }\end{array}$ & 6 & 3 & 3 & 5 \\
\hline \multicolumn{2}{|c|}{ Coxopleural pores } & 50 & $21-22$ & 20 & $23-24$ \\
\hline
\end{tabular}


Table 3 (continued). Main morphological characters of the eight known Asian species of Tygarrup Chamberlin, 1914.

\begin{tabular}{|c|c|c|c|c|c|}
\hline \multicolumn{2}{|c|}{ Tygarrup species } & T. crassignathus & T. singaporiensis & T. takarazimensis & T. triporus \\
\hline \multicolumn{2}{|c|}{ Description from } & Titova (1983) & Verhoeff (1937) & Miyoshi (1957) & Titova (1983) \\
\hline \multirow{2}{*}{$\begin{array}{l}\text { Clypeal } \\
\text { setae (pair) }\end{array}$} & areolate part & 0 & 0 & 1 & 1 \\
\hline & plagula & $2-3$ & 12 & 10 & $6-7$ \\
\hline \multirow[b]{2}{*}{ Mandible } & lamellae & 6 & $4-5$ & 8 & 6 \\
\hline & $\begin{array}{l}\text { teeth of } 1^{\text {st }} \\
\text { lamella }\end{array}$ & 5 & $?$ & 5 & 5 \\
\hline \multicolumn{2}{|c|}{ Coxopleural pore } & ? (numerous) & 40 & 20 & ? (numerous) \\
\hline
\end{tabular}

\section{Order Lithobiomorpha Pocock, 1895}

Family Lithobiidae Newport, 1844

Genus Australobius Chamberlin, 1920

Australobius cangshanensis Chao, Lee, Yang \& Chang, sp. nov.

(Figures 12-25)

Material examined. Holotype: ô (NMNS81 03-007), forest floor, Cangshan, Dali City, Yunnan Province, $25^{\circ} 42^{\prime} \mathrm{N}, 100^{\circ} 07^{\prime} \mathrm{E}, 2500 \mathrm{~m}, 29$ Aug 2010, leg. H.B. Pu, K.C. Zhang \& Z.Z.

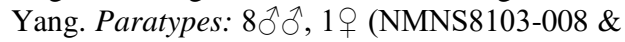
009): same data as holotype. Other material: 4우우 (NMNS8103-010), same locality as holotype, 12 Jul 2010, leg. H.B. Pu; 1 우 (NMNS8103-011), forest floor, Weibaoshan, Weishan County, Yunnan Province, $25^{\circ} 10^{\prime} \mathrm{N}$, $100^{\circ} 21^{\prime}$ E, 2501m, 11 Nov 2018, leg. J.L. Chao;

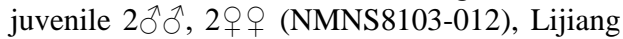
City, Yunnan Province, 08 May 2011, leg. H.W. Chang.

Etymology. Refers to the type locality.

Diagnosis. A species of the genus Australobius Chamberlin, 1920, normally with $23+23$ elongate antennal articles; body length approximately $26 \mathrm{~mm}$; cephalic plate markedly wider than all tergites; 7-8 ocelli, $[1+4(3), 3]$, posterior ocellus comparatively large. Tömösváry's organ smaller than adjacent ocelli; forcipular coxosternite with 7-10 coxosternal teeth, porodont between $5^{\text {th }}$ and $6^{\text {th }}$ or between $4^{\text {th }}$ and $5^{\text {th }}$ innermost teeth; posterior angles of all tergites lacking triangular projections; a transverse row of about 60 short setae transversely on the posterior part of both $6^{\text {th }}$ and $7^{\text {th }}$ sternites; coxal pores 5-7, ovate; female gonopods with 3-5 slender spurs, terminal claw undivided; male gonopods with two long setae.

Description. Body length: $26 \mathrm{~mm}$. Body colour: dark brown (Fig. 12). Antennae with 23 articles; all articles markedly longer than wide; distal article much longer than wide, up to 3.9 times as long as wide (Fig. 13); abundant setae on antennal surface, less so on basal articles, gradual increase in density to around fourth article, then more or less constant in number. Cephalic plate smooth, width subequal to length, posterior marginal ridge moderately broader and weakly concave; cephalic plate markedly wider than all tergites (Fig. 14), setae scattered sparsely over whole surface. Seven or eight ocelli on each side, $[1+4(3), 3]$, one posterior, three or four dorsal, three ventral, arranged in two irregular rows; posterior ocellus comparatively large; ocelli domed, translucent, usually darkly pigmented (Figs. 15-16). Tömösváry's organ comparatively small, nearly rounded; situated under the second ventral seriate ocellus, smaller than adjacent ocelli (Figs. 15-16). Forcipular coxosternite subtrapezoidal, anterior margin narrow, external side slightly longer than internal side; median longitudinal cleft moderately deep; anterior border with $10+9$ large triangular coxosternal teeth in the adult, or with $7+8$ teeth in juveniles; porodont slender, between $5^{\text {th }}$ and $6^{\text {th }}$ innermost teeth in 

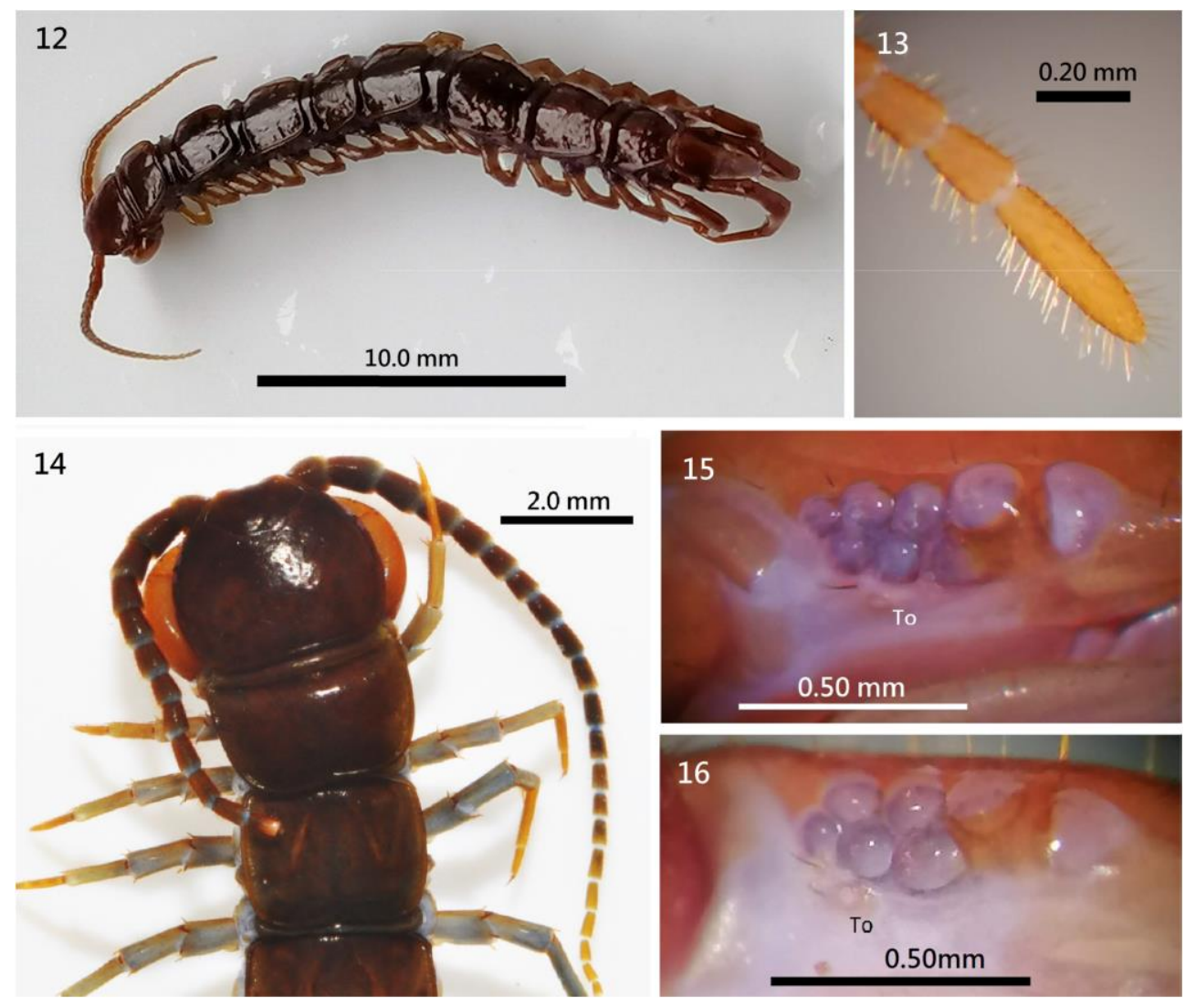

Figures 12-16. Australobius cangshanensis sp. nov. $12=$ habitus, dorsal view; $13=$ distal articles of antennae; $14=$ head and anterior trunk; 15 = eight ocelli and Tömösváry's organ (To) on left side; 16 = seven ocelli and Tömösváry's organ on left side (12-13: NMNS8103-007; 14: NMNS 8103-011; 15: NMNS8103-007; 16: NMNS8103-012).

specimens with a total of 9 or 10 teeth (Figs. 17-18), between $4^{\text {th }}$ and $5^{\text {th }}$ innermost teeth in those with a total of 7 or 8 teeth (Fig. 19); some scattered setae on the ventral side of coxosternite.

Tergites smooth, without wrinkles, back side slightly hunched; T1 generally trapeziform, posterior margin narrower than anterior margin; T1 slightly narrower than cephalic plate, wider than other tergites; posterior margin of TT1, 3 and 5 weakly concave; posterior margin of TT8, $10,12,14$ and 15 deeply concave. TT1, 3, 5, 8, 10 and 12 with continuous lateral and posterior marginal ridges, other tergites with lateral mar- ginal ridges. Posterior angles of all tergites lacking triangular projections; tiny setae scattered very sparsely over the surface. Sternites narrower posteriorly, generally trapeziform, comparatively smooth, setae emerging from pores scattered very sparsely over the surface. A transverse row of about 60 short setae on the posterior part of both $6^{\text {th }}$ and $7^{\text {th }}$ sternites (Figs. 20-21). Legs: tarsi welldefined on all legs; all legs with fairly long claws, curved ventrally; anterior and posterior accessory spines on legs 1-13, anterior accessory spines slender and short, posterior one thick and long, posterior accessory spine longer than anterior one; legs14 and 15 lack accessory spines. Leg plectrotaxy as in Table 4. 

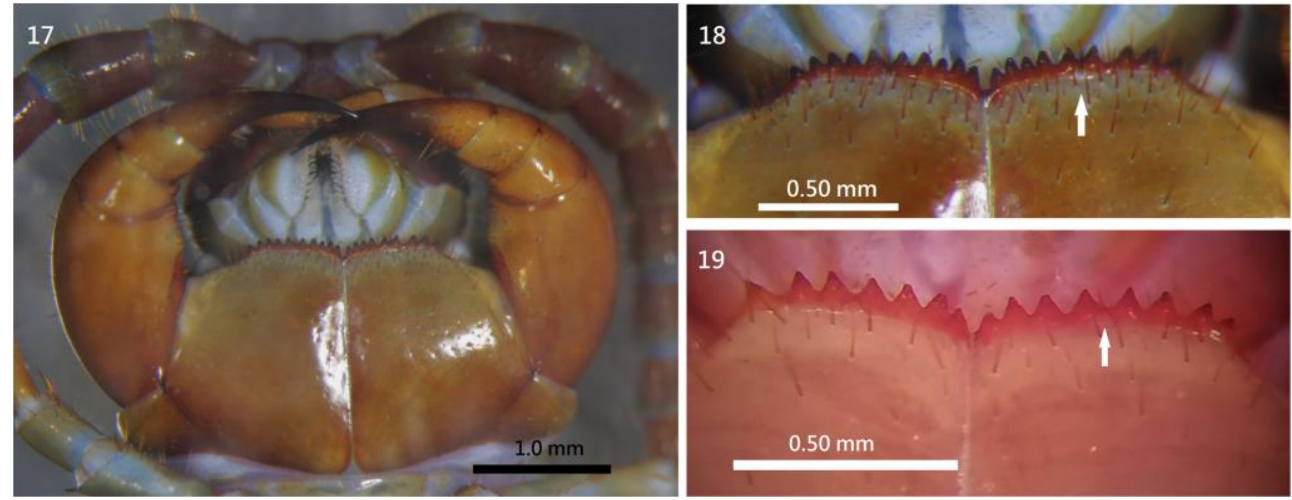

Figures 17-19. Australobius cangshanensis sp. nov. $17=$ head and forcipules, ventral view; $18=$ porodont nodes (arrow) between $5^{\text {th }}$ and $6^{\text {th }}$ innermost coxosternal teeth; $19=$ porodont nodes (arrow) between $4^{\text {th }}$ and $5^{\text {th }}$ innermost coxosternal teeth (17-18: NMNS 8103-011; 19: NMNS8103-012).

Table 4. Leg plectrotaxy of Australobius cangshanensis sp. nov.

\begin{tabular}{|c|c|c|c|c|c|c|c|c|c|c|}
\hline \multirow{2}{*}{ leg pairs } & \multicolumn{5}{|c|}{ Ventral } & \multicolumn{5}{|c|}{ Dorsal } \\
\hline & C & $\mathbf{t}$ & $\mathbf{P}$ & $\mathbf{F}$ & $\mathbf{T i}$ & C & $\mathbf{t}$ & $\mathbf{P}$ & $\mathbf{F}$ & $\mathbf{T i}$ \\
\hline 1 & - & - & ap & $\mathrm{m}$ & $\mathrm{m}$ & - & - & ap & $\mathrm{a}$ & $\mathrm{a}$ \\
\hline $2-5$ & - & - & ap & amp & am & - & - & ap & ap & $\mathrm{a}$ \\
\hline 6-13 & - & - & ap & amp & amp & - & - & amp & ap & ap \\
\hline 14 & - & $\mathrm{m}$ & amp & amp & ap & $\mathrm{m}$ & - & amp & $\mathrm{p}$ & - \\
\hline 15 & - & $\mathrm{m}$ & amp & amp & $\mathrm{a}$ & $\mathrm{m}$ & - & amp & - & - \\
\hline
\end{tabular}

Coxal pores: 6665 in males, 7777 in females, ovate; coxal pore field set in a relatively shallow groove, margin of coxal pore-field with slightly eminence (Figs. 22-24). Male sternite 15: generally trapeziform, posterolaterally narrower than anterolaterally, posterior margin concave, long setae scattered sparsely over the surface (Fig. 22). Male first genital sternite: wider than long, usually well chitinized; posterior margin quite deeply concave between the gonopods, without a medial bulge; comparatively long setae scattered evenly on ventral surface; male gonopods short and small, as a semispherical bulge with 2 long setae, apically slightly chitinized (Fig. 23). Female sternite 15: generally trapeziform, anterolaterally broader than posterolaterally, posterior margin straight, long setae scattered sparsely over the surface; sternite of the genital segment well chitinized, wider than long; posterior margin of the genital sternite straight; short to long setae sparsely scattered over the ventral surface of genital segment (Fig. 24). Female gonopod: first article fairly broad, bearing 15-18 long setae, arranged in three irregular rows; $3-5$ slender spurs, inner spur smaller; second article with 8-10 rather long setae arranged in two irregular rows on its ventral side; third article usually with 3-5 long setae on its ventral surface; terminal claw undivided (Fig. 25).

Remarks. Seven species of Australobius have hitherto been described from China (Ma et al. 2008a, 2008b, Qin et al. 2014, Li et al. 2018, Dyachkov 2017). Ma et al. (2008b) first described A. nodulus from Tibet, as with a transverse band of setae on the posterior part of both $6^{\text {th }}$ and $7^{\text {th }}$ sternites in male; 11 ocelli, $[2+4,5]$, posterior ocellus largest, penultimate ocellus large, other ocelli small, and arranged in two 
rows; $6+6$ coxosternal teeth. Li et al. (2018) described A. tracheoperspicuus from Guizhou, with $6^{\text {th }}$ and $7^{\text {th }}$ sternites with about 30 setae each, arranged in two irregular rows; no ocelli; and $5+5$ coxosternal teeth. However, Australobius cangshanensis sp. nov. has a row of ca. 60 setae on each $6^{\text {th }}$ and $7^{\text {th }}$ sternites; with a different ocelli arrangement, and with more coxosternal teeth.
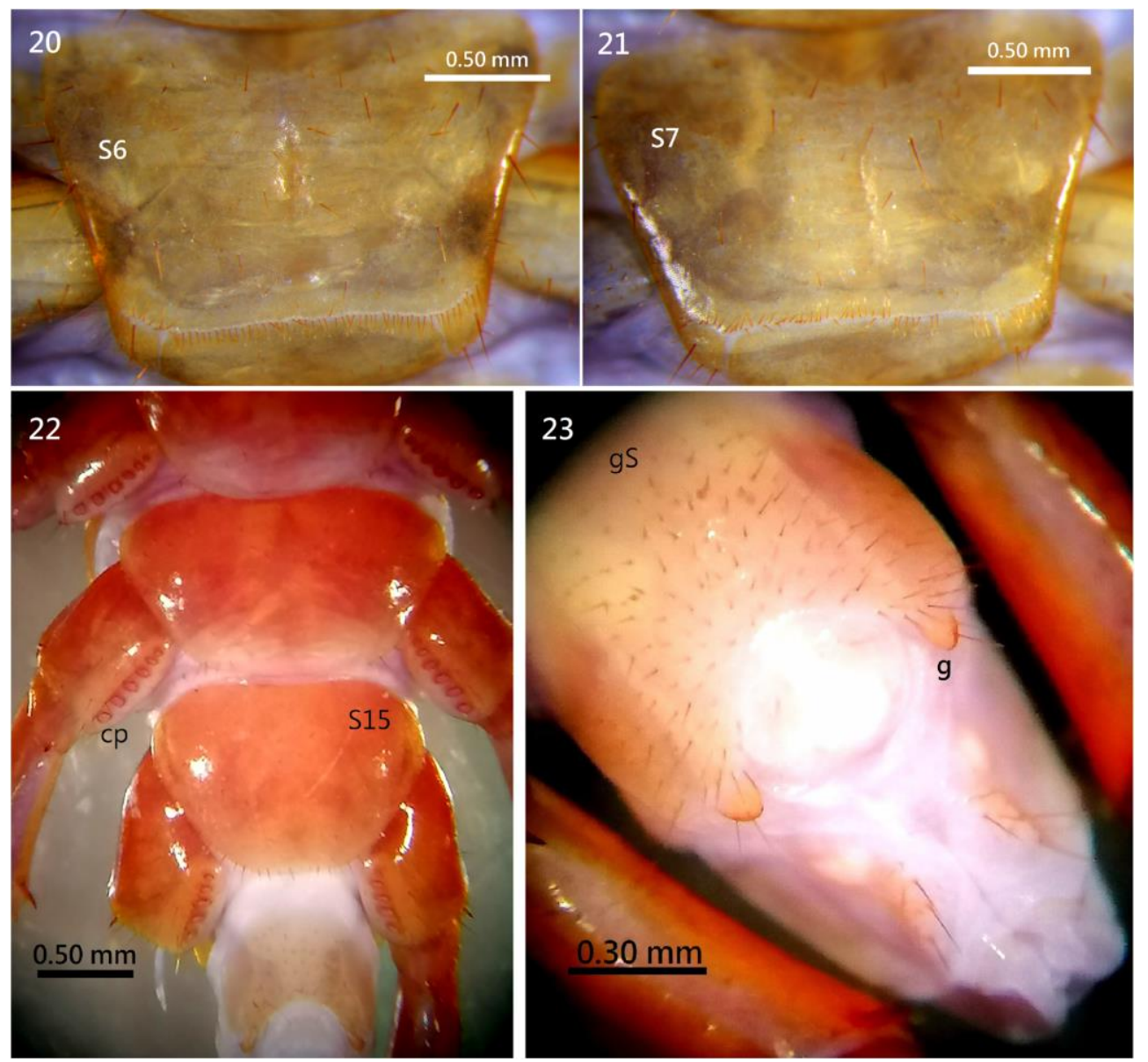

Figures 20--23. Australobius cangshanensis sp. nov. $20=6^{\text {th }}$ sternite (S6); $21=7^{\text {th }}$ sternite (S7); $22=$ coxal pores (cp) of $13-15^{\text {th }}$ legs, $15^{\text {th }}$ sternite (S15); 23 = male first genital sternite $(\mathrm{gS})$ and male gonopods $(\mathrm{g})$ (20-21: NMNS 8103-011; 22-23: NMNS8103-008). 


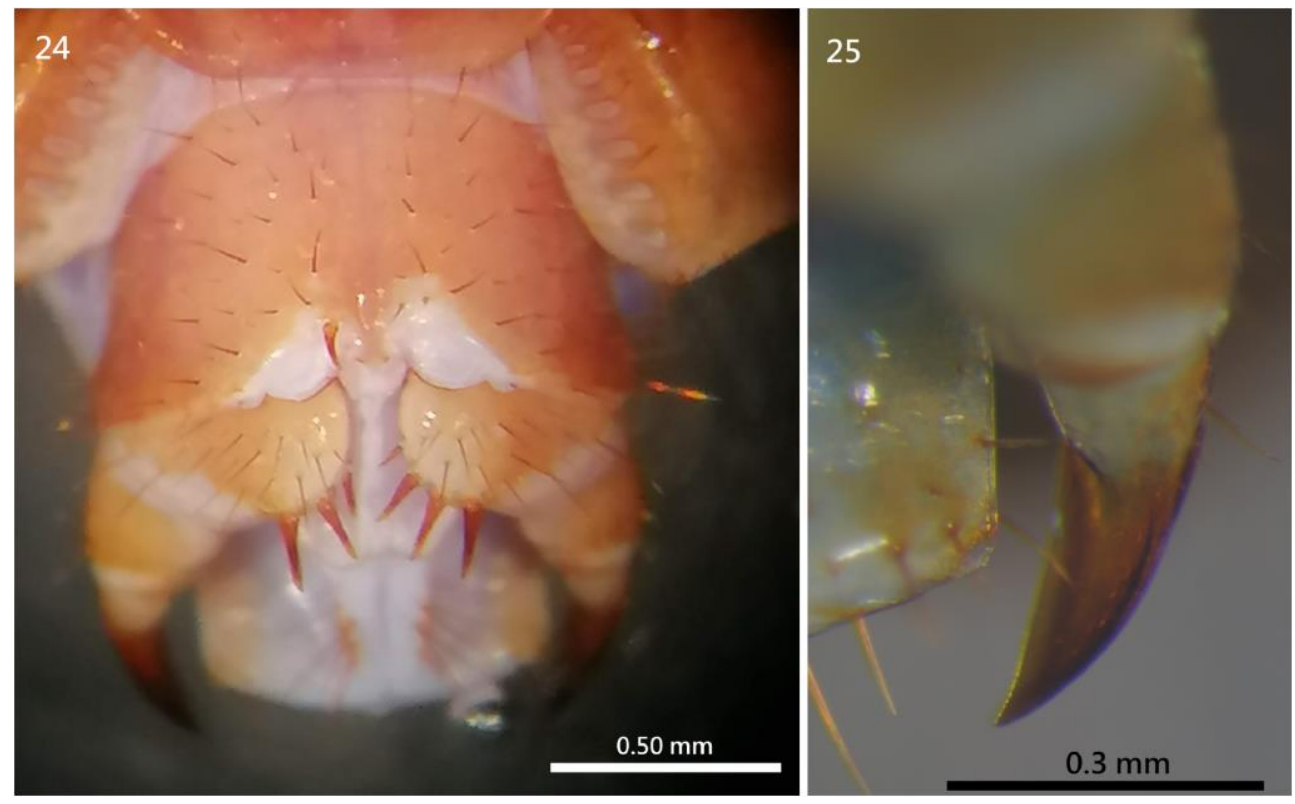

Figure 24-25. Australobius cangshanensis sp. nov. $24=$ coxal pores of $15^{\text {th }}$ legs, female first genital sternite and female gonopods; 25 = claw of female gonopod (24-25: NMNS 8103-011).

\section{Key to the known Chinese species of the genus Australobius Chamberlin, 1920}

1. At least four ocelli on each side of cephalic plate . .2

- No ocelli on cephalic plate A. tracheoperspicuus Li, Pei, Guo, Ma \& Chen, 2018

2. Four ocelli on each side of cephalic plate, Tömösváry's organ larger than adjacent ocelli ..... tetrophthalmus (Loksa, 1960)

- More than seven ocelli on each side of cephalic plate, Tömösváry's organ smaller than adjacent ocelli ....3

3. Porodonts present

- No prodonts A. apicicornis $\mathrm{Qin}, \mathrm{Lin}, \mathrm{ZhaO} \mathrm{Li}$ Xie, Ma, Su \& Zhang, 2014

4. Large posterior tergites wrinkled; a bulge present on terminal part of male $15^{\text {th }}$ tibiae A. magnus (Trozina, 1894)

- Large posterior tergites smooth; no bulge on the terminal part of male $15^{\text {th }}$ tibiae
5. Antenna with 31 articles; 5-6 forcipular coxosternal teeth ... A. nodulus Ma, Song \& Zhu, 2008

- Antenna with less than 31 articles

6. Antenna with 29 articles; 7-8 small blunt forcipular coxosternal teeth

A. polyspinipes Ma, Liu, Lu, Hou \& Pei, 2018

- Antenna with less than 29 articles

7. Antenna with 26 articles; 2-4 forcipular coxosternal teeth ... .A. anamagnus $\mathrm{Ma}$, Song \& Zhu, 2008

- Antenna with 23 articles; 7-10 triangular forcipular coxosternal teeth A. cangshanensis sp. nov.

Acknowledgements - We are grateful to Dr. Gregory D. Edgecombe for everlasting help during our study. Thanks to Dali University for their specimens. Thanks also to Ms. ShaoKang $\mathrm{Hu}$ for preparing the SEM micrographs, and to $\mathrm{Mr}$. Shih-Chen Chang for translating the Japanese literature. We are deeply obliged to Prof. Huiqin Ma, Dr. Lászlo Dányi, Dr. Lucio Bonato and Dr. Alexandr Evsyukov for their help with literature. 


\section{REFERENCES}

Bonato, L., Edgecombe, G.D., Lewis, J.G.E., Minelli, A., Pereira, L.A., Shelley, R.M. \& ZAPPAROLI, M. (2010): A common terminology for the external anatomy of centipedes (Chilopoda). ZooKeys, 69: 17-51.

doi: $\underline{10.3897 / \text { zookeys.69.737 }}$

Bonato, L., FodDai, D. \& Minelli, A. (2004): The centipede order Geophilomorpha in the Hawaiian islands (Chilopoda). Bishop Museum Occasional papers, 78: 13-32.

Bonato, L. \& MinelLi, A. (2010): The geophilomorph centipedes of the Seychelles (Chilopoda, Geophilomorpha). Phelsuma, 18: 9-38.

CHAMBerlin, R.V. (1920): The Myriopoda of the Australian region. Bulletin of the Museum of Comparative Zoology. Harvard College, 64: 1269.

CRABILL, R.E. (1968): A bizzare case of sexual dimorphism in a centipede with consequent submergence of a genus (Chilopoda: Geophilomorpha: Mecistocephalidae). Entomological News, 79: 286-287.

DyachKov, Y.V. (2017): New data on the Australobius magnus (Trotzina, 1894) (Chilopoda: Lithobiomorpha: Lithobiidae) from Southern Kazakhstan. Ukrainian Journal of Ecology, 7(4): 440-443. doi: $10.15421 / 2017 \_139$

Edgecombe, G.D. \& Hollington, L.M. (2002): Morphology and distribution of Australobius scabrior (Chilopoda, Lithobiomorpha, Lithobiidae). Memoirs of the Queensland Museum, 48(1): 103-118.

LI, Q., PeI, S., GuO, X., MA, H. \& ChEN, H.M. (2018): Australobius tracheoperspicuus sp. n., the first subterranean species of centipede from southern China (Lithobiomorpha, Lithobiidae). ZooKeys, 795: 83-91. doi: $10.3897 /$ zookeys.795.28036

LOKSA, I. (1960): Einige neue Diplopoden-und Chilopoden-Arten aus Chinesischen Höhlen. Acta Zoologica Academiae Scientiarum Hungaricae, 6: 135-148.

MA, H., Liu, H., Lu, Y., Hou, X. \& PeI, S. (2018): Australobius polyspinipes sp. n., a new species of Austalobius Chamberlin, 1920 (Lithobiomorpha,
Lithobiidae) from China. Entomologica Fennica, 29: 146-152. doi: $10.33338 /$ ef.77285

MA, H., SONG, D. \& ZHU, M. (2008a): A new species of the genus Australobius Chamberlin, 1920 (Lithobiomorpha: Lithobiidae) from Tibet, China. Entomological News, 2: 171-177.

doi: $10.3157 / 0013-$ 872X(2008)119[171:ANSOTG]2.0.CO;2

MA, H., SonG, D. \& ZHU, M. (2008b): A new species of Australobius Chamberlin from China (Lithobiomorpha, Lithobiidae). Oriental Insects, 42: 335340. doi: $10.1080 / 00305316.2008 .10417558$

MATIC, Z. (1970): Contribution à la connaissance des Lithobiides (Chilopoda, Lithobiomorpha) de Corée. Annales Zoologici Warszawa, 28: 55-63.

MiYoshi, Y. (1957): Beiträge zur Kenntnis japanischer Myriopoden 20. Aufsatz: Über eine neue Gattung von Diplopoda, eine neue Art und eine neue Unterart von Chilopoda. Zoological Magazine, Tokyo, 66 (6): 265-266.

QIN, W., Lin, G., ZHAO, X., LI, B., XIE, J., MA, H., Su, J. \& ZHANG, T. (2014): A new species of Australobius (Lithobiomorpha, Lithobiidae) from the Qinghai-Tibet Plateau, China. Biologia, 69(11): 1601-1605. doi: 10.2478/s11756-014-0459-4

SHINOHARA, K. (1965): A new species of Chilopoda from Himalaya. Journal of the College of Arts and Sciences, Chiba University, 4(3): 303-306.

Titova, L.P. (1983): Two new Tygarrup Chamb. (Chilopoda, Geophilida, Mecistocephalidae) from Indochina. Annalen des Naturhistorischen Museums in Wien, 85(B): 147-156.

TrotzinA, A. (1894): Vier neue Lithobius-Arten aus Central Asia. Horae Societatis Entomologicae Rossicae, 28: 247-253.

Uliana, M., Bonato, L. \& Minelli, A. (2007): The Mecistocephalidae of the Japanese and Taiwanese islands (Chilopoda, Geophilomorpha). Zootaxa, 1936: 1-84. doi: 10.11646/zootaxa.1396.1.1

VerHOEFF, K.W. (1937). Chilopoden aus Malacca nach den Objecten des Raffles Museum in Singapore. Bulletin of the Raffles Museum, 13: 198270.

VERHOEFF, K.W. (1942): Chilopoden aus innerasiatischen Hochgebirgen. Zoologischer Anzeiger, 137: 35-52. 